\title{
ANALISIS FAKTOR-FAKTOR YANG MEMPENGARUHI HASIL BELAJAR PRODUK KREATIF DAN KEWIRAUSAHAAN
}

\author{
Corry Yohana \\ Fakultas Ekonomi, Universitas Negeri Jakarta \\ e-mail: Corryyohana20@gmail.com
}

\begin{abstract}
Received: 02 Oktober 2020; Revised: 21 November 2020; Accepted: 28 Desember 2020 DOI: http://dx.doi.org/10.37905/aksara.7.1.89-102.2021
\end{abstract}

\begin{abstract}
ABSTRAK
Penelitian ini mengkaji factor-faktor yang menghubungkan hasil belajar Produk Kreaktif dan Kewirausahaan. Tujuan penelitian ini adalah mengetahui signifikansi pengaruh Kreativitas Belajar dan Kemandirian Belajar dengan Hasil Belajar Produk Kreaktif dan Kewirausahaan di SMK Negeri Jakarta. Metode penelitian yang digunakan adalah metode survei dengan pendekatan korelasional, populasi diambil dari seluruh siswa SMK Negeri Jakarta. Jumlah sampel sebanyak 131 responden diambil dengan menggunakan teknik simple random sampling. Tehnik analisis dalam penelitian ini adalah regresi linear berganda. Persamaan regresi yang dihasilkan adalah $\hat{Y}=63,008+0,160 X_{1}+0,132 X_{2}$. Dari hasil uji signifikansi simultan (Uji F) menghasilkan $F_{\text {hitung }}>F_{\text {tabel }}$ yaitu 100,183 > 3,066, sehingga dapat disimpulkan bahwa persamaan regresi tersebut signifikan. Kemudian dilakukan uji $\mathrm{t}$ dan dihasilkan $\mathrm{Y}$ atas $\mathrm{X}_{1} \mathrm{t}_{\text {hitung }}=7,844$ dan $\mathrm{t}_{\text {tabel }}=1,65685, \mathrm{Y}$ atas $\mathrm{X}_{2} \mathrm{t}_{\text {hitung }}=6,315$ dan $\mathrm{t}_{\text {tabel }}=1,65685$. Dapat disimpulkan bahwa koefisien korelasinya adalah positif dan signifikan. Koefisien determinasi $\mathrm{Y}$ atas $\mathrm{X}_{1}$ dan $\mathrm{X}_{2}$ diperoleh sebesar 0,610 yang menunjukkan bahwa 61,0\% variabel hasil belajar ditentukan oleh kreativitas belajar dan Kemandirian Belajar.

Berdasarkan hasil penelitian, guru dan siswa ada baiknya memperhatikaan faktor-faktor kreativitas belajar dan Kemandirian Belajar sebagai bahan pertimbangan dalam mengaplikasikan hasil belajar produk kreatif dan kewirausahaan, karena variabel ini secara signifikan berpengaruh positif terhadap hasil belajar produk kreatif dan kewirausahaan
\end{abstract}

Kata Kunci : Hasil Belajar, Kreativitas Belajar, Kemandirian Belajar

\section{ABSTRACT}

This study examines the factors which link learning outcomes, creative product and entrepeneurship. The purpose of this research is to understand the significance of the influence of learning creativity and learning independence with learning outcomes of creative and entrepreneurial products at public high vocational school. The number of samples of this research is 131 respondents. It was taken using simple random sampling technique. The analysis technique which has been used in this research is multiple linear regression. The resulting regression equation is $\hat{Y}=63.008+0.160 X_{1}+0.132 X_{2}$. From the results of the simultaneous significance test (Test $F$ ) produces Fcount> Ftable, namely 100.183> 3.066, so it can be concluded that the regression equation is significant. Then the $T$-test was performed and the resulting $Y$ on $X_{1}$ tcount $=7.844$ and t table $=$ 1.65685, $Y$ on $X_{2}$ tcount $=6.315$ and $t$ table $=1.65685$. It can be concluded that the correlation coefficient is positive and significant. The coefficient of $Y$ determination on 
Volume : 07

Nomor : 01

Bulan : Januari

Tahun : 2021

http://ejurnal.pps.ung.ac.id/index.php/AKSARA/index

$X_{1}$ and $X_{2}$ is 0.610 which indicates that $61.0 \%$ of the learning outcome variable is determined by learning creativity and learning independence. Based on the results of the research, teachers and students should pay attention to the factors of learning creativity and learning independence as consideration in applying learning outcomes of creative and entrepreneurial products, because these variables have a significant positive effect on learning outcomes of creative and entrepreneurial products.

Keywords: Learning Outcomes, Learning Creativity, Learning Independence

\section{PENDAHULUAN}

Pendidikan merupakan suatu hal yang sangat pokok dalam kehidupan setiap manusia. Selain itu, pendidikan juga merupakan sarana dimana peserta didik mampu mengembangkan potensi diri dan keterampilan untuk membuat dirinya berguna bagi masyarakat karena pendidikan memiliki peranan penting dalam pembangunan suatu negara.

Dalam survei kualitas pendidikan yang keluarkan oleh PISA, Indonesia menempati peringkat ke-72 dari 77 negara. Pengamat menilai kompetensi guru yang rendah dan sistem pendidikan yang terlalu kuno menjadi penyebabnya. Rendahnya mutu pendidikan di Indonesia diantara negara lain adalah hambatan utama dalam menghasilkan sumber daya manusia yang berkualitas. Hal ini disebabkan sistem pendidikan di Indonesia belum maksimal. (p.dw.com 2019)

Kegiatan belajar mengajar adalah faktor yang menentukan mutu siswa. Jadi bisa dikatakan bahwa berhasil atau tidaknya tujuan pendidikan tergantung pada bagaimana cara belajar mengajar di dalam kelas. Keberhasilan belajar mengajar ditandai dengan adanya nilai atau output yang dicapai oleh siswa. Rendahnya hasil belajar di sekolah tersebut disebabkan oleh beberapa factor, diantaranya adalah rendahnya Kemandirian Belajar dan rendahnya kreativitas belajar siswa Kreativitas belajar sangat diperlukan siswa untuk meningkatkan hasil belajar. Pada umumnya, orang menghubungkan kreativitas belajar dengan produk kreasi; dengan perkataan lain, produk kreasi itu merupakan hal yang penting untuk menilai kreativitas belajar. Seperti siswa yang memiliki sifat suka menciptakan sesuatu, berkomitmen kepada tugas, suka berimajinasi dan mampu beradaptasi ke lingkungan sekitar. Dengan kreativitas belajar yang dimilikinya, siswa tersebut akan berusaha semaksimal mungkin untuk mendapatkan hasil belajar yang tinggi sesuai yang ia harapkan.

Dalam artikel online, yaitu media Okenews (okenews 2018) memberitakan bahwa melihat kurikulum kita belum berani bercengkrama atau setidaknya bersinggungan dengan imajinasi dan kreativitas. Berdasarkan berita di atas rendahnya kreativitas siswa dalam belajar disebabkan oleh kurikulum yang lebih memfokuskan capaian-capaian portofolio dan lebih mementingkan pengetahuan (kognitif). Kurikulum itu ternyata berdampak pada cara belajar siswa. Siswa pun menjadi mekanistis: apa adanya dan miskin ide-ide yang menggugah imajinasi.

Dalam proses pendidikan siswa, faktor kedua yang dapat mempengaruhi hasil belajar siswa adalah Kemandirian Belajar siswa. Kemandirian Belajar adalah hal yang penting dalam proses belajar mengajar. Kemandirian yang dimaksud adalah sifat yang cenderung tidak bergantung kepada orang lain. Seperti siswa berinisiatif menyelesaikan tugas maupun masalahnya sendiri. Dan mampu belajar dengan kemauan dari diri sendiri tanpa 
dipaksa oleh orang lain. Dengan Kemandirian Belajar yang dimilikinya, siswa tersebut akan berusaha semaksimal mungkin untuk mendapatkan hasil belajar yang tinggi sesuai yang ia harapkan. Saat ini siswa dituntut untuk memiliki kemandirian dalam belajar, hal ini diatur dalam kurikulum 2013 revisi.

Kemandirian dalam diri siswa dapat terbentuk yang berawal dari niat dalam diri sendiri. Kemudian terdapat dukungan dari orang tua dan guru sebagai tenaga pendidik di sekolah. Dengan adanya kemandirian pada siswa diharapkan siswa dapat mudah mengerti pelajaran yang diajarkan dan mudah dalam mengerjakan sesuatu sesuai dengan kemampuan yang dimiliki.

Kementerian Pendidikan dan Kebudayaan ( Kemdikbud) menetapkan 6 profil pelajar Indonesia. Adapun 6 profil itu disebut sebagai Profil Pelajar Indonesia Pancasila.yakni: Bernalar kritis dan dapat memecahkan masalah,. Harus mandiri, Harus kreatif, Punya sikap gotong royong, Sikap kebhinekaan global dan berakhlak mulia (https://www.kompas.com/edu/read/2020/05/07/13 0140471/mendikbud-nadiem-ini-6profil-pelajar-indonesia).

Berdasarkan pengamatan yang dilakukan peneliti pada saat proses belajar mengajar, ketika guru sedang memberikan materi pelajaran yang mengharuskan siswa untuk diskusi namun yang terjadi di dalam kelas adalah banyak siswa yang acuh pada saat sesi diskusi di kelas. Kemudian pada saat ulangan juga masih banyak siswa yang mencontek, hal ini menunjukan siswa yang belum dapat mengatur dan mengorganisasikan dirinya untuk mencapai kemandirian dalam belajar.

Dalam pembelajaran tentu ada tujuan yang ingin dicapai oleh siswa, tujuan tersebut adalah hasil belajar. Hasil belajar merupakan bagian terpenting dalam sebuah pembelajaran. Hasil belajar seringkali digunakan sebagai tolak ukur untuk mengetahui sejauh mana penguasaan siswa mengenai materi yang diajarkan. Menurut Sudjana (2010) hasil belajar adalah kemampuan-kemampuan yang dimiliki siswa setelah ia menerima pengalaman belajarnya.

Selanjutnya, menurut Susanto (2014) mengatakan bahwa, hasil belajar adalah perubahan perilaku yang berupa pengetahuan atau pemahaman, keterampilan dan sikap yang diperoleh peserta didik selama berlangsungnya proses belajar mengajar atau yang lazim disebut dengan pembelajaran.

Berdasarkan pernyataan-pernyataan di atas, hasil belajar adalah kemampuan yang dimiliki siswa setelah siswa melalui proses belajar mengajar.

Secara keseluruhan dapat disimpulkan bahwa hasil belajar adalah kemampuan yang diperoleh dan perubahan yang terjadi pada diri siswa setelah melalui proses belajar mengajar yang dinyatakan dalam bentuk skor dan diperoleh dari hasil tes mata pelajaran tertentu. Hasil belajar diambil dari data Ulangan Akhir Semester genap

Kreativitas merupakan istilah yang banyak digunakan baik di lingkungan sekolah maupun di luar sekolah. Slameto (2010) menjelaskan, pada hakikatnya pengertian kreatif berhubungan dengan penemuan sesuatu, mengenai hal yang menghasilkan sesuatu yang baru dengan menggunakan sesuatu yang telah ada.

Terdapat beragam definisi yang terkandung dalam pengertian kreativitas belajar. Menurut pandangan David Campbell dalam Beni (2012), kreativitas belajar adalah suatu ide atau pemikiran manusia yang bersifat inovatif, berdaya guna, dan dapat dimengerti.

Jadi, kreativitas belajar merupakan kemampuan seseorang melahirkan karya baru dengan menggunakan kombinasi dari hal-hal yang sudah ada sehingga relatif berbeda dari 
Volume : 07

Nomor : 01

Bulan : Januari

Tahun : 2021

http://ejurnal.pps.ung.ac.id/index.php/AKSARA/index

karya yang telah ada, yang pada dasarnya dimiliki oleh setiap individu. Kreativitas belajar dapat diukur dengan indikator memiliki rasa ingin tahu yang besar, sering mengajukan pertanyaan yang berbobot, memberikan banyak gagasan dan usul terhadap suatu masalah, mampu menyatakan pendapat secara spontan dan tidak malu-malu, mempunyai atau menghargai keindahan, mempunyai pendapat sendiri dan dapat mengungkapkannya memiliki rasa humor tinggi, mempunyai daya imajinasi yang kuat, mampu mengajukan pemikiran, gagasan pemecahan masalah yang berbeda dari orang lain (orisinil), dapat bekerja sendiri.

Kemandirian Belajar adalah sikap seseorang yang secara kesadaran diri sendiri dan dengan percaya diri untuk belajar untuk dirinya sendiri. Seperti yang dikemukakan oleh Morrison (2012) bahwa, kemandirian adalah kemampuan untuk mengerjakan tugas sendiri, menjaga diri sendiri, dan memulai kegiatan tanpa harus selalu diberi tahu apa yang harus dilakukan.

Watson \& Lindgren dalam Nurhayati (2011) mengemukakan pendapat bahwa, kemandirian berarti kebebasan untuk mengambil inisiatif, mengatasi hambatan, melakukan sesuatu dengan tepat, gigih dalam usaha, dan melakukan sendiri segala sesuatu tanpa bantuan orang lain.

Dari kedua teori di atas dapat ditarik kesimpulan bahwa Kemandirian Belajar adalah kemampuan menjaga diri sendiri dan mengendalikan pikiran, perasaan, dan tindakan sendiri secara bebas tanpa harus ragu-ragu atau diberi tahu apa yang harus dilakukan.

Jadi disimpulkan bahwa Kemandirian Belajar adalah proses pembelajaran yang lebih banyak memberikan kebebasan kepada siswa untuk tanggung jawab, inisiatif, percaya diri dan memiliki hasrat bersaing dalam menentukan kebutuhan belajarnya sendiri untuk dirinya sendiri. Kemandirian Belajar dapat diukur dengan lima indikator, yaitu tanggung jawab (disiplin dan berani mengambil resiko), inisiatif (berpikir kreatif dan sesuai tujuan), percaya diri (optimis dan percaya dengan kemampuan sendiri), memiliki hasrat bersaing (mampu berkompetisi) dan mampu mengambil keputusan.

Berdasarkan penelitian yang sudah dilakukan sebelumnya menjelaskan bahwa faktor-faktor yang mempengaruhi hasil belajar digolongkan menjadi 2 golongan yaitu factor intern yaitu emosi, sikap negatip terhadap mata pelajaran, minat, bakat, intelegensi, kreativitas. Sedangkan ekstern yaitu factor social dan non social, Sunaryo (2004). Salah satu faktor kecedasan yang mempengaruhi hasil belajar adalah kreativitas, Habsari, (2005). Penenelitian yang dilakukan sebelumnya oleh Wilda, Salwah dan Shindi Ekawati (2017), Ahmad Zamhuri (2017), Ni Kadek Lia Wulandari dan I Wayan Sudiarsa (2016), Devi Setyowati dan I Wayan Widana (2016) menghasilkan kreativitas berpengaruh signifikan terhadap hasil belajar.

Penelitian yang dilakukan oleh Umi Kulsum, Djoko Kustono dan Purnomo (2017), Syamsu Rijal dan Suhaedir Bachtiar (2015), Naglaa Fathy Mahmoud 2015), Ni Kadek Lia Wulandari dan I Wayan Sudiarsa (2016) berdasarkan hasil penelitian bahwa Kemandirian Belajar berpengaruh positif dan signifikan terhadap hasil belajar. Kemandirian Belajar merupakan salah satu faktor yang mampu mempengaruhi hasil belajar seseorang. Hal ini diungkapkan oleh beberapa ahli yang menyatakan bahwa Kemandirian Belajar mempengaruhi hasil belajar siswa.

Dari beberapa penelitian yang sudah dilakukan sebelumnya menjelaskan bahwa kreativitas belajar dan Kemandirian Belajar mempengaruhi hasil belajar. Maka dari itu peneliti tertarik untuk meneliti pengaruh tersebut yang di uji cobakan kepada responden 
lain, selain itu peneliti tertarik untuk mengetahui apakah factor-faktor yang mempengaruhi hasil belajar produk kreatif dan kewirausahanpada siswa SMK Negeri Jakarta

Perumusan hipotesis dapat dirumuskan sebagai berikut:

$\mathrm{H1}$ :kreativitas belajar secara signifikan berpengaruh positif terhadap hasil belajar pada Siswa SMKN di Jakarta.

$\mathrm{H} 2$ :Kemandirian Belajar secara signifikan berpengaruh positif dan signifikan terhadap hasil belajar pada Siswa SMKN di Jakarta.

H3:kreativitas belajar dan Kemandirian Belajar berpengaruh positif dan signifikan terhadap hasil belajar pada Siswa SMKN di Jakarta

\section{METODE}

Penelitian ini dilakukan di SMKN Jakarta dengan mengunakan pendekatan kuatitatif berbentuk asosiasi. Siswa SMKN adalah subyek dalam penelitian ini. Hasil belajar Produk Kreatif dan kewirausahaan adalah obyek penelitian ini. Jenis data yang digunakan terdiri dari data kuantitatif dan data kualitatif. Data kuantitatif yaitu data jumlah siswa SMKN Jakarta dan data kualitatif yang merupakan tanggapan dari responden yang diuraikan dalam kuesioner. Berdasarkan sumbernya, jenis data yang digunakan dalam penelitian ini adalah data primer yang diperoleh dari jawaban siswa SMKN yang terpilih sebagai responden penelitian sesuai dengan kriteria yang ditentukan serta data sekunder yang diperoleh dari bagian administrasi SMKN Jakarta

\section{Populasi dan Sampel}

siswa SMKN Jakarta yang sudah menempuh mata pelajaran Produk Kreatif dan kewirausahaan dijadikan populasi target. Sampel dalam penelitian ini sebanyak 131 responden diambil dengan menggunakan teknik Purposive. Sugiyono (2014)

Metode pengumpulan data dengan penyebaran kuesioner dan skala pengukuran data yang digunakan adalah skala Likert. Jawaban setiap item instrumen yang menggunakan skala Likert mempunyai gradasi dari sangat negatif sampai sangat positif. Teknik analisis data yang digunakan adalah regresi linear berganda.

\section{Hasil dan Pembahasan}

Hasil

Profil Responden

Penelitian dilakukan di Jakarta. 113 siswa telah dipilih sebagai responden, terdiri dari 37 laki-laki $(16,9 \%)$ dan 94 perempuan $(83,1 \%)$ siswa.

Tabel 1 Profil Respnden

\begin{tabular}{|l|l|l|}
\hline Jenis kelamin & Frekuensi & $\%$ \\
\hline Laki-laki & 37 & 16,9 \\
\hline Prempuan & 94 & 83,1 \\
\hline Jumlah & 113 & 100 \\
\hline
\end{tabular}

Sumber: Data Primer Diolah, 2019 
Volume : 07

Nomor : 01

Bulan : Januari

Tahun : 2021

http://ejurnal.pps.ung.ac.id/index.php/AKSARA/index

Hasil pengujian instrumen penelitian

Tabel 2. Hasil Uji Instrumen Penelitian

\begin{tabular}{|l|l|l|l|l|}
\hline No & Variabel & Item Penyataan & Korelasi item & Keterangan \\
\hline 1 & $\begin{array}{l}\text { Hasil Belajar } \\
\text { produk kratif dan } \\
\text { kewirausahaan }\end{array}$ & - & - & menggunakan ledger nilai UAS \\
& & & yang diambil dari siswa kelas XI \\
SMK Negeri 16 di Jakarta.
\end{tabular}

Sumber: Data Primer Diolah,2018

Hasil uji validitas menunjukkan bahwa, seluruh pernyataan menunjukkan nilai rhitung > rtabel pada nilai signifikansi 5 persen. Dengan demikian, dapat dijelaskan bahwa seluruh indikator dalam kuesioner penelitian ini adalah valid dan dapat digunakan sebagai instrumen penelitian. 
Tabel 3. Hasil Uji Instrumen Penelitian

\begin{tabular}{|l|l|l|}
\hline Variabel & $\begin{array}{l}\text { Cronbach's } \\
\text { Alpha }\end{array}$ & Keterangan \\
\hline Kreativitas belajar (X1) & 0,803 & Reliabel \\
\hline Kemandirian Belajar(X2) & 0,882 & Reliabel \\
\hline
\end{tabular}

Disisi lain, hasil uji reliabilitas menunjukkan bahwa kedua instrumen penelitian memiliki koefisien Cronbach's Alpha lebih dari 0,60. Dengan kata lain dapat dikatakan semua instrumen reliabel sehingga dapat digunakan dalam melakukan penelitian.

\section{Deskripsi variabel penelitian}

Tabel 4. Deskripsi Jawaban Responden Terhadap Variabel Penelitian

\begin{tabular}{|c|c|c|c|}
\hline Variabel & Penyataan & Jumlah Soal & Persentase \\
\hline \multirow{9}{*}{$\begin{array}{l}\text { Kreativitas } \\
\text { belajar (X1) }\end{array}$} & Memiliki rasa ingin tahu yang besar & 1 Soal & $12,69 \%$ \\
\hline & $\begin{array}{l}\text { Sering mengajukan pertanyaan yang } \\
\text { berbobot }\end{array}$ & 1 Soal & $12,26 \%$ \\
\hline & $\begin{array}{l}\text { Memberikan banyak gagasan dan usul } \\
\text { terhadap suatu masalah }\end{array}$ & 2 Soal & $12,50 \%$ \\
\hline & $\begin{array}{l}\text { Mampu menyatakan pendapat secara } \\
\text { spontan dan tidak malu-malu }\end{array}$ & 2 Soal & $12,38 \%$ \\
\hline & $\begin{array}{l}\text { Mempunyai pendapat sendiri dapat } \\
\text { mengungkapkannya }\end{array}$ & 2 Soal & $12,41 \%$ \\
\hline & Mempunyai daya imajinasi yang kuat & 2 Soal & $12,33 \%$ \\
\hline & $\begin{array}{l}\text { Mampu mengajukan pemikiran, gagasan } \\
\text { pemecahan masalah yang berbeda dari orang } \\
\text { lain (orisinil) }\end{array}$ & 2 Soal & $12,38 \%$ \\
\hline & Dapat bekerja sendiri & 2 Soal & $12,59 \%$ \\
\hline & Rata-rata & & $12,44 \%$ \\
\hline \multirow{9}{*}{$\begin{array}{l}\text { Kemandirian } \\
\text { Belajar(X2) }\end{array}$} & Disiplin & 4 Soal & $12,52 \%$ \\
\hline & Berani dalam mengambil resiko & 2 Soal & $12,29 \%$ \\
\hline & Sesuai dengan tujuan & 2 Soal & $12,24 \%$ \\
\hline & Berpikir kreatif & 4 Soal & $12,57 \%$ \\
\hline & Yakin dengan kemampuan diri sendiri & 4 Soal & $12,47 \%$ \\
\hline & Optimis & 3 Soal & $12,66 \%$ \\
\hline & Mampu berkompetisi & 3 Soal & $12,49 \%$ \\
\hline & Mampu Mengambil Keputusan & 3 Soal & $12,76 \%$ \\
\hline & Rata-rata & & $12,50 \%$ \\
\hline
\end{tabular}

Berdasarkan hasil rata - rata hitung skor masing - masing indikator dari variabel kreativitas belajar terlihat bahwa indikator rata-ratanya adalah $12,44 \%$ dan yang memiliki skor tertinggi adalah indikator" Memiliki rasa ingin tahu yang besar, sebesar 12,69\%" hal ini berarti responden memiliki rasa ingin tahu yang besar berbeda dgn orang lain yang sangat tinggi dalam Kreativitas belajar dan indikator yang memiliki skor terendah adalah indikator sering mengajukan pertanyaan yang berbobot sebesar 12,26\%. dan masuk dalam kriteria sangat tinggi, ini berarti bahwa responden memiliki kreativitas belajar yang tinggi.

Berdasarkan hasil rata-rata hitung skor masing-masing indikator dari variabel Kemandirian Belajar terlihat bahwa indikator rata-ratanya adalah $12,50 \%$ dan yang 
memiliki skor tertinggi adalah indikator" mampu mengambil keputusan" sebesar 12,76\% hal ini berarti responden memiliki kemampuan mengambil keputusan dan indikator yang memiliki skor rata-rata terendah adalah indikator inisiatif yaitu sesuai dengan tujuan sebesar $12,24 \%$. dan masuk dalam kriteria rendah, ini berarti bahwa responden lebih memilih inisiatif sesuai dengan tujuan. hal ini berarti responden memiliki Kemandirian Belajar yang tinggi.

\section{Pengujian Persyaratan Analisis}

a. Uji Normalitas

\section{Tabel 5 Hasil Uji Normalitas}

\begin{tabular}{|c|c|c|}
\hline \multicolumn{3}{|c|}{ One-Sample Kolmogorov-Smirnov Test } \\
\hline & & $\begin{array}{l}\text { Unstandardized } \\
\text { Residual }\end{array}$ \\
\hline \multicolumn{2}{|l|}{$\mathrm{N}$} & 131 \\
\hline \multirow[t]{2}{*}{ Normal Parameters ${ }^{\mathrm{a}, \mathrm{b}}$} & Mean & .0000000 \\
\hline & Std. Deviation & 2.09541302 \\
\hline \multirow[t]{3}{*}{ Most Extreme Differences } & Absolute & .048 \\
\hline & Positive & .048 \\
\hline & Negative & -.022 \\
\hline \multicolumn{2}{|l|}{ Test Statistic } & .048 \\
\hline \multicolumn{2}{|l|}{ Asymp. Sig. (2-tailed) } & $.200^{\mathrm{c}, \mathrm{d}}$ \\
\hline \multicolumn{3}{|c|}{ a. Test distribution is Normal. } \\
\hline \multicolumn{3}{|l|}{ b. Calculated from data. } \\
\hline \multicolumn{3}{|c|}{ c. Lilliefors Significance Correction. } \\
\hline
\end{tabular}

Hasil uji normalitas menunjukkan bahwa, nilai Kolmogorov-Smirnov menyimpulkan bahwa ketiga variabel berdistribusi normal. Hal ini dapat dibuktikan dengan hasil perhitungan dengan tingkat signifikansi bernilai sebesar 0,200. Tingkat signifikansi tersebut $>0,05$. Dengan demikian, maka data tersebut berdistribusi normal.

b. Uji Linieritas

Tabel 6. Uji Persamaan Regresi Linier Berganda

\begin{tabular}{|c|c|c|c|c|c|c|}
\hline \multicolumn{7}{|c|}{ Coefficients $^{\mathbf{a}}$} \\
\hline \multirow{2}{*}{\multicolumn{2}{|c|}{ Model }} & \multicolumn{2}{|c|}{$\begin{array}{l}\text { Unstandardized } \\
\text { Coefficients }\end{array}$} & \multirow{2}{*}{$\begin{array}{l}\text { Standardized } \\
\text { Coefficients } \\
\text { Beta }\end{array}$} & \multirow[b]{2}{*}{$\mathrm{t}$} & \multirow[b]{2}{*}{ Sig. } \\
\hline & & $\mathrm{B}$ & Std. Error & & & \\
\hline \multirow[t]{3}{*}{1} & (Constant) & 63.008 & 1.897 & & 33.218 & .000 \\
\hline & Kreativitas Belajar & .160 & .020 & .499 & 7.844 & .000 \\
\hline & $\begin{array}{l}\text { Kemandirian } \\
\text { Belajar }\end{array}$ & .132 & .021 & .402 & 6.315 & .000 \\
\hline
\end{tabular}

Berdasarkan hasil analisis regresi linier berganda diperoleh persamaan regresi linier pengaruh antara kreativitas belajar $\left(\mathrm{X}_{1}\right)$ dan Kemandirian Belajar $\left(\mathrm{X}_{2}\right)$ dengan hasil belajar (Y), yaitu $\hat{Y}=63,008+0,160 \mathrm{X}_{1}+0,132 \mathrm{X}_{2}$. 


\section{Uji Signifikansi Simultan (Uji F)}

Tabel 7. Uji Signifikansi Simultan (Uji F) $X_{1}$ dan $X_{2}$ terhadap $Y$

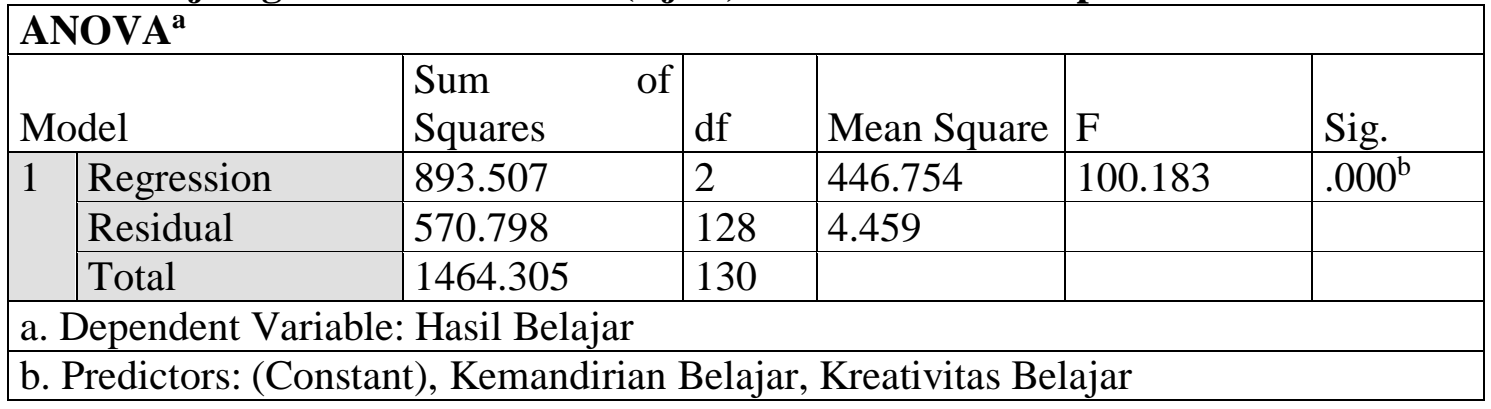

Dari tabel diatas, maka dapat dilihat bahwa nilai $F_{\text {hitung }}$ sebesar 100,183 > nilai $F_{\text {tabel }}$ sebesar 3,066 dapat disimpulkan bahwa kreativitas belajar dan Kemandirian Belajar secara simultan berpengaruh terhadap hasil belajar.

\section{Uji Siginifikansi Parsial (Uji t)}

Tabel 8. Uji Signifikansi Parsial (Uji t) $\mathrm{X}_{1}$ terhadap Y

\begin{tabular}{|c|c|c|c|c|c|c|}
\hline \multicolumn{7}{|c|}{ Coefficients $^{\mathrm{a}}$} \\
\hline \multirow{2}{*}{\multicolumn{2}{|c|}{ Model }} & \multicolumn{2}{|c|}{$\begin{array}{l}\text { Unstandardized } \\
\text { Coefficients }\end{array}$} & \multirow{2}{*}{$\begin{array}{l}\text { Standardized } \\
\text { Coefficients } \\
\text { Beta }\end{array}$} & \multirow[b]{2}{*}{$\mathrm{t}$} & \multirow[b]{2}{*}{ Sig. } \\
\hline & & B & Std. Error & & & \\
\hline 1 & (Constant) & 63.008 & 1.897 & & 33.218 & .000 \\
\hline & Kreativitas Belajar & .160 & .020 & .499 & 7.844 & .000 \\
\hline & $\begin{array}{l}\text { Kemandirian } \\
\text { Belajar }\end{array}$ & .132 & .021 & .402 & 6.315 & .000 \\
\hline
\end{tabular}

Hasil dari tabel uji $\mathrm{t}$ diatas diperolah $\mathrm{t}_{\text {hitung }}$ dari kreativitas belajar sebesar 7,844>> $\mathrm{t}_{\text {tabel }}=1,65685$ Dengan demikian, dapat disimpulkan bahwa koefisien adalah signifikan. Artinya dapat dikatakan bahwa terdapat pengaruh positif antara kreativitas belajar terhadap hasil belajar.

Tabel 9. Uji Signifikansi Parsial (Uji t) $\mathbf{X}_{2}$ terhadap Y

\section{Coefficients $^{\mathrm{a}}$}

\begin{tabular}{|c|c|c|c|c|c|c|}
\hline \multirow{2}{*}{\multicolumn{2}{|c|}{ Model }} & \multicolumn{2}{|c|}{$\begin{array}{l}\text { Unstandardized } \\
\text { Coefficients }\end{array}$} & \multirow{2}{*}{\begin{tabular}{|l} 
Standardized \\
Coefficients \\
Beta \\
\end{tabular}} & \multirow[b]{2}{*}{$\mathrm{t}$} & \multirow[b]{2}{*}{ Sig. } \\
\hline & & $\mathrm{B}$ & Std. Error & & & \\
\hline & (Constant) & 63.008 & 1.897 & & 33.218 & .000 \\
\hline & Kreativitas Belajar & .160 & .020 & .499 & 7.844 & .000 \\
\hline & Kemandirian Belajar & .132 & .021 & .402 & 6.315 & .000 \\
\hline
\end{tabular}

a. Dependent Variable: Hasil Belajar

Hasil dari tabel uji t diatas diperolah $\mathrm{t}_{\text {hitung }}$ dari Kemandirian Belajar sebesar 6,315

$>\mathrm{t}_{\text {tabel }}=1,65685$. Dengan demikian, dapat disimpulkan bahwa koefisien adalah signifikan. Artinya dapat dikatakan bahwa terdapat pengaruh positif antara Kemandirian Belajar terhadap hasil belajar. 
Uji Analisis Korelasi Ganda

Tabel 10 Uji Analisis Korelasi Ganda

\begin{tabular}{|c|c|c|c|c|}
\hline \multicolumn{5}{|l|}{ Correlations } \\
\hline & & $\begin{array}{l}\text { Kreativitas } \\
\text { Belajar }\end{array}$ & $\begin{array}{l}\text { Kemandirian } \\
\text { Belajar }\end{array}$ & $\begin{array}{l}\text { Hasil } \\
\text { Belajar }\end{array}$ \\
\hline \multirow[t]{3}{*}{ Kreativitas Belajar } & $\begin{array}{l}\text { Pearson } \\
\text { Correlation }\end{array}$ & 1 & $.498^{* *}$ & $.699^{* *}$ \\
\hline & Sig. (2-tailed) & & .000 & .000 \\
\hline & $\mathrm{N}$ & 131 & 131 & 131 \\
\hline \multirow[t]{3}{*}{$\begin{array}{l}\text { Kemandirian } \\
\text { Belajar }\end{array}$} & $\begin{array}{l}\text { Pearson } \\
\text { Correlation }\end{array}$ & $.498^{* * *}$ & 1 & $.650^{* *}$ \\
\hline & Sig. (2-tailed) & .000 & & .000 \\
\hline & $\mathrm{N}$ & 131 & 131 & 131 \\
\hline \multirow[t]{3}{*}{ Hasil Belajar } & $\begin{array}{l}\text { Pearson } \\
\text { Correlation } \\
\end{array}$ & $.699^{* *}$ & $.650^{* *}$ & 1 \\
\hline & Sig. (2-tailed) & .000 & .000 & \\
\hline & $\mathrm{N}$ & 131 & 131 & 131 \\
\hline
\end{tabular}

Diketahui bahwa nilai signifikansi dari output di atas antara kreativitas belajar $\left(\mathrm{X}_{1}\right)$ dengan Kemandirian Belajar $\left(\mathrm{X}_{2}\right)$ memiliki nilai signifikansi $0,000<0,05$. Artinya terdapat korelasi yang signifikan. Selanjutnya, antara kreativitas belajar $\left(\mathrm{X}_{1}\right)$ dengan hasil belajar (Y) nilai signifikansi $0,000<0,05$ yang berarti terdapat korelasi yang signifikan. Terakhir, antara Kemandirian Belajar $\left(\mathrm{X}_{2}\right)$ dengan hasil belajar $(\mathrm{Y})$ nilai signifikansi $0,000<0,05$ yang berarti terdapat korelasi yang signifikan.

\section{Uji Koefisien Determinasi}

Tabel 11. Uji Koefisien Determinasi Kreativitas Belajar $\left(X_{1}\right)$ dan Kemandirian Belajar dengan Hasil Belajar

\begin{tabular}{|l|l|l|l|l|}
\hline \multicolumn{4}{|l|}{ Model Summary } & Adjusted R Square \\
Model & $\mathrm{R}$ & R Square & $\begin{array}{l}\text { Std. Error of the } \\
\text { Estimate }\end{array}$ \\
\hline 1 & $.781^{\mathrm{a}}$ & .610 & .604 & 2.112 \\
\hline a. Predictors: (Constant), Kemandirian Belajar, Kreativitas Belajar \\
\hline
\end{tabular}

Dari tabel diatas hasil hitung uji koefisien determinasi dapat diketahui nilai $\mathrm{R}^{2}$ sebesar 0,610. Sehingga kemampuan dari variabel kreativitas belajar dan Kemandirian Belajar untuk menjelaskan hasil belajar secara simultan yaitu 61,0\% sedangkan 39,0\% sisanya dipengaruhi oleh variabel lain.

Tabel 12. Uji Koefisien Determinasi Kreativitas Belajar $\left(X_{1}\right)$ dengan Hasil Belajar

\begin{tabular}{|l|r|r|r|c|}
\hline \multicolumn{6}{|c|}{ Model Summary } \\
\hline Model & $\mathrm{R}$ & R Square & Adjusted R Square & $\begin{array}{c}\text { Std. Error of the } \\
\text { Estimate }\end{array}$ \\
\hline 1 & $.699^{\mathrm{a}}$ & .489 & .485 & 2.409 \\
\hline a. Predictors: (Constant), Kreativitas Belajar \\
\hline
\end{tabular}


Dari tabel diatas hasil hitung uji koefisien determinasi dapat diketahui nilai $\mathrm{R}^{2}$ sebesar 0,489 . Sehingga kemampuan dari variabel kreativitas belajar untuk menjelaskan hasil belajar secara parsial yaitu $48,9 \%$ sedangkan $51,1 \%$ sisanya dipengaruhi oleh variabel lain.

Tabel 1. Uji Koefisien Determinasi Kemandirian Belajar $\left(\mathbf{X}_{2}\right)$ dengan Hasil Belajar

\begin{tabular}{|l|l|l|l|l|}
\hline \multicolumn{5}{|c|}{ Model Summary } \\
\hline Model & $\mathrm{R}$ & R Square & Adjusted R Square & $\begin{array}{l}\text { Std. Error of the } \\
\text { Estimate }\end{array}$ \\
\hline 1 & $.650^{\mathrm{a}}$ & .423 & .418 & 2.560 \\
\hline a. Predictors: (Constant), Kemandirian Belajar \\
\hline
\end{tabular}

Dari tabel diatas hasil hitung uji koefisien determinasi dapat diketahui nilai $\mathrm{R}^{2}$ sebesar 0,423. Sehingga kemampuan dari variabel Kemandirian Belajar untuk menjelaskan hasil belajar secara parsial yaitu $42,3 \%$ sedangkan $57,7 \%$ sisanya dipengaruhi oleh variabel lain.

\section{Pembahasan}

\section{Pengaruh Kreaktivitas Belajar Terhadap Hasil Belajar}

Pengujian hipotesis pada kreativitas belajar terhadap hasil belajar menunjukan bahwa kreativitas belajar secara signifikan berpengaruh positif terhadap hasil belajar. Dari uji $t$ diperolah $t_{\text {hitung }}$ dari kreativitas belajar sebesar 7,844 $>t_{\text {tabel }}=1,65685$ Dengan demikian, dapat disimpulkan signifikan. Artinya dapat dikatakan bahwa terdapat pengaruh positif antara kreativitas belajar terhadap hasil belajar. Ini berarti setiap peningkatan Kreattivitas Belajar akan mengakibatkan Hasil Belajar di SMK akan meningkat.

Koefisien Derteminasi sebesar sebesar 0,489. hal ini menunjukan 48,9\% variabel Hasil Belajar ditentukan oleh faktor Kreaktivitas Belajar sedangkan sisanya 51,1 oleh faktor lain.

Hasil penelitian ini mendukung temuan oleh Wilda, Salwah dan Shindi Ekawati (2017), Ahmad Zamhuri (2017), Ni Kadek Lia Wulandari dan I Wayan Sudiarsa (2016), Devi Setyowati dan I Wayan Widana(2016) yangmenjelaskan bahwa Kreaktivitas Belajar secara signifikan berpengaruh positif terhadap Hasil Belajar.

\section{Pengaruh Kemandirian Belajar Terhadap Hasil Belajar}

Pengujian hipotesis pada Kemandirian Belajar terhadap Hasil Belajar menunjukan bahwa Kemandirian Belajar secara signifikan berpengaruh positif terhadap Hasil Belajar. Dari uji t diperolah $t_{\text {hitung }}$ dari Kemandirian Belajar sebesar 6,315 $>\mathrm{t}_{\text {tabel }}=$ 1,65685. Dengan demikian, dapat disimpulkan signifikan. Artinya dapat dikatakan bahwa terdapat pengaruh positif antara Kemandirian Belajar terhadap hasil belajar. Ini berarti setiap peningkatan Kemandirian Belajar akan mengakibatkan Hasil Belajar di SMK akan meningkat. Koefisien Derteminasi sebesar sebesar 0,423. hal ini menunjukan 42,3\% variabel Hasil Belajar ditentukan oleh faktor Kreaktivitas Belajar sedangkan sisanya 51,1 oleh faktor lain.

Hasil penelitian ini mendukung temuan oleh Devi Setyowati dan I Wayan Widana (2016) serta Wilda, Salwah dan Shindy Ekawati (2017) 
Volume : 07

Nomor : 01

Bulan : Januari

Tahun : 2021

http://ejurnal.pps.ung.ac.id/index.php/AKSARA/index

\section{Pengaruh kreaktivitas Belajar dan Kemandirian Belajar Terhadap Hasil Belajar}

Pengujian hipotesis pada Kreaktivitas Belajar dan Kemandirian Belajar terhadap Hasil Belajar menunjukan bahwa Kreaktivitas Belajar dan Kemandirian Belajar secara signifikan berpengaruh positif terhadap Hasil Belajar. Dari uji $\mathrm{f}$ diperolah $\mathrm{f}_{\text {hitung }}$ dari Kreaktivitas Belajar dan Kemandirian Belajar sebesar 100,183 > nilai $F_{\text {tabel }}$ sebesar 3,066 dapat disimpulkan bahwa kreativitas belajar dan Kemandirian Belajar secara simultan berpengaruh terhadap hasil belajar. Dengan demikian, dapat disimpulkan signifikan. Artinya dapat dikatakan bahwa terdapat pengaruh positif antara Kreaktivitas Belajar dan Kemandirian Belajar terhadap hasil belajar. Ini berarti setiap peningkatan Kreaktivitas Belajar dan Kemandirian Belajar akan mengakibatkan Hasil Belajar di SMK akan meningkat. Koefisien Derteminasi sebesar 0,610. hal ini menunjukan sebesar $61 \%$ variabel Hasil Belajar ditentukan oleh faktor Kreaktivitas Belajar dan Kemandirian Belajar sedangkan sisanya 39\% oleh faktor lain. Hasil penelitian ini mendukung temuan oleh Umi Kulsum, Djoko Kustono dan Purnomo (2017) serta Syamsu Rijal dan Suhaedir Bachtiar (2015)

\section{Implikasi}

Berdasarkan hasil penelitian yang diperoleh, terdapat beberapa implikasi yang dihasilkan. Pertama, di dalam variabel Kreaktivitas Belajar didapat hasil bahwa indikator "Memiliki rasa ingin tahu yang besar, Dapat bekerja sendiri, Memberikan banyak gagasan dan usul terhadap suatu masalah" indikator ini memiliki nilai rata-rata tertinggi dibandingkan indikator lainnya, kemudian total rata-rata sebesar 12,44 dari seluruh pernyataan tentang Kreaktivitas Belajar mendapatkan keterangan sangat tinggi. Artinya bahwa siswa SMK yang Memiliki rasa ingin tahu yang besar, Dapat bekerja sendiri, Memberikan banyak gagasan dan usul terhadap suatu masalah memiliki Kreaktivitas Belajar tinggi, ini dapat dijadikan acuan bagi pihak sekolah untuk lebih meningkatkan Kreaktivitas Belajar siswasehingga Hasil Belajar akan tinggi

Kedua di dalam variable Kemandirian Belajar didapatkan hasil bahwa indicator diatas rata-rata sebesar 12,50 adalah "Disiplin, Berpikir kreatif, Optimis dan Mampu Mengambil Keputusan" Artinya bahwa siswa SMK yang Disiplin, Berpikir kreatif, Optimis dan Mampu Mengambil Keputusan memiliki Kemandirian Belajar Yang tinggi, ini dapat dijadikan acuan bagi pihak sekolah untuk lebih meningkatkan Kemandirian Belajar Siswa sesuai indicator diatas rata-rata sehingga Hasil Belajar akan tinggi.

\section{Simpulan}

Berdasarkan pada hasil pengujian hipotesis diperoleh kesimpulan bahwa terdapat hubungan yang signifikan antara dengan Kreaktivitas Belajar terhadap Hasil Belajar siswa SMK, kemudian terdapat hubungan yang signifikan antara Kemandirian Belajar terhadap Hasil Belajar siswa SMK. Adapun hubungan regresi bersifat linier secara bersama-sama terdapat pengaruh positif yang signifikan antara variabel bebas Kreaktivitas Belajar (X1) dan Kemandirian Belajar (X2) dengan variabel terikat Hasil Belajar siswa SMK (Y). 


\section{Saran}

Berdasarkan kesimpulan dan implikasi yang telah dikemukakan di atas, maka peneliti memberikan saran yang diharapkan dapat menjadi masukan yang bermanfaat, antara lain:

1. Diketahui indikator terendah pada variabel kreativitas belajar yaitu sering mengajukan pertanyaan yang berbobot. Hal ini menandakan siswa jarang mengajukan pertanyaan - pertanyaan yang berbobot selama proses belajar. Peneliti menyarankan kepada siswa untuk lebih aktif untuk mengajukan pertanyaan kepada guru supaya proses pembelajaran dapat tercapai dengan maksimal dengan hasil belajar yang baik.

2. Diketahui indikator terendah pada variabel Kemandirian Belajar yaitu inisiatif dengan sub indikator sesuai dengan tujuan. Hal ini menandakan bahwa banyak siswa yang belum menentukan target saat belajar dan masih sulit berkonsentrasi dalam belajar. Peneliti menyarankan kepada siswa untuk dapat menentukan targetnya saat belajar dan berusaha untuk lebih berkonsentrasi dalam belajar supaya siswa dapat memperoleh hasil belajar yang maksimal.

\section{DAFTAR PUSTAKA}

Ahmad Zamhuri dengan judul "Pengaruh Kreativitas Siswa dan Fasilitas Belajar Terhadap Prestasi Belajar Pendidikan Agama Islam di SMAN Se-Kecamatan XIII Koto Kampar Kabupaten Kampar" HIKMAH : Jurnal Pendidikan Islam Vol. 6, No. 1 Januari - Juni 2017. P-ISSN: 2085-8663, E-ISSN: 2450-5611.

Beni S. Ambarjaya. Psikologi Pendidikan dan Pengajaran. Yogyakarta: CAPS. 2012

Devi Setyowati dan I Wayan Widana, Pengaruh Minat, Kepercayaan Diri, Dan Kreativitas Belajar Terhadap Hasil Belajar Matematika. Jurnal Emasains, Vol. 5, No. 1, Maret 2016, ISSN: 2302-2124.

George, Morrison. Dasar-Dasar Pendidikan Anak Usia Dini. Jakarta: Indeks. 2012.

Habsari, Sri. Bimbingan dan Konseling SMA untuk kelas XI. Jakarta: Grasindo. 2005.

Hessy Trishandiani, Inovasi dan Kreativitas, Tuntutan Utama Pendidikan Zaman Now (https://news.okezone.com/read/2018/4/13/ Inovasi dan Kreativitas, Tuntutan Utama Pendidikan Zaman Now). Diakses pada tanggal 26 Maret 2019.

Jamaris, Martini. Orientasi Baru dalam Psikologi Pendidikan. Jakarta: Yayasan Penamas Murni. 2010.

Naglaa Fathy Mahmoud dengan judul "The Effect of Self- Learning Package Versus Lecture Method on Students' Intended Learning Outcomes". World Journal of Nursing Sciences, 2015, ISSN: 2222-1352.

Naglaa Fathy Mahmoud, The Effect of Self-Learning Package Versus Lecture Method on Students' Intended Learning Outcomes. World Journal of Nursing Sciences, 2015, ISSN: 2222-1352.

Ni Kadek Lia Wulandari dan I Wayan Sudiarsa dengan judul, Hubungan Antara Kecerdasan Emosional, Kemandirian Dan Kreativitas Belajar Dengan Hasil Belajar Matematika Peserta Didik Kelas X SMA Negeri 1 Sukawati. Jurnal Emasains, Vol. 5, No. 1, Maret 2016, ISSN 2302-2124.

Nurhayati, Eti. Psikologi Pendidikan Inovatif. Yogyakarta: Pustaka Belajar. 2011.

Slameto. Belajar dan Faktor-Faktor yang Mempengaruhinya. Jakarta: PT. Rineka Cipta. 2010. 
Volume : 07

Nomor : 01

Bulan : Januari

Tahun : 2021

http://ejurnal.pps.ung.ac.id/index.php/AKSARA/index

Sudjana, Nana. Penilaian Hasil Proses Belajar Mengajar. Bandung: PT Remaja Rosdakarya. 2010.

Sugiyono. 2014. Metode Penelitian Bisnis (Pendekatan Kuantitatif, Kualitatif, dan $R \& D)$. Bandung: Alfabeta.

Sunaryo. Psikologi Untuk Keperawatan. Jakarta : EGC. 2004.

Susanto, Ahmad. Pengembangan Pembelajaran IPS di Sekolah Dasar. Jakarta: Prenadamedia Group. 2014

Syamsu Rijal dan Suhaedir Bachtiar dengan judul Hubungan antara Sikap, Kemandirian Belajar, dan Gaya Belajar dengan Hasil Belajar Kognitif Siswa. Jurnal Bioedukatika, Vol. 3, No. 2, Desember 2015, ISSN: 2338-6630.

Syamsu Rijal dan Suhaedir Bachtiar, Hubungan antara Sikap, Kemandirian Belajar, dan Gaya Belajar dengan Hasil Belajar Kognitif Siswa. Jurnal Bioedukatika, Vol. 3, No. 2, Desember 2015, ISSN: 2338-6630.

Umi Kulsum, Djoko Kustono dan Purnomo, Improvement of Learning Independence and Learning Outcomes on Textile Course through Hybrid Learning Model. IOSR Journal Of Humanities And Social Science, Vol. 22, Issue 8, 2017, ISSN: 22790845

Wibowo, Kreativitas dan Pendidikan Kita, (http://mediaindonesia.com/read /detail/38101-kreativitas-dan-pendidikan-kita, diakses padatanggal 26 Maret 2019). Diakses pada tanggal 26 Maret 2019.

Wilda, Salwah dan Shindy Ekawati, Pengaruh Kreativitas dan Minat Belajar Terhadap Hasil Belajar Matematika Siswa. Jurnal Pedagogy, Vol. 2, No. 1, ISSN: 25023802 . 